\title{
Categorisation of Industrial Side Streams for Reuse Potential Evaluation
}

\author{
Tero Leppänen \\ University of Oulu, Finland \\ tero.leppanen@oulu.fi \\ Juhoantti Köpman \\ University of Oulu, Finland \\ juho.kopman@gmail.com \\ Oskari Rasila \\ University of Oulu, Finland \\ oskari.rasila@pp.inet.fi \\ Pekka Tervonen \\ University of Oulu, Finland \\ pekka.tervonen@oulu.fi
}

Purpose: Industries are creating vast amounts of side streams with many underutilised potentials that a circular economy could harness. Different types of side streams present various challenges and opportunities in terms of their reuse. Thus, it would be beneficial for these industrial side streams to be categorised according to their properties affecting their reuse potential.

\begin{abstract}
Study design/methodology/approach: The empirical data for this multiple case study was gathered from industries in Northern Ostrobothnia, Finland. Data collection included company visits, interviews, workshops, seminars, and the collection of existing documentation from the cases, and the data was collected by multiple investigators. The empirical data was analysed using descriptive qualitative methods.

Findings: Similarities between industrial side streams of processes were found not to originate from either the industry the process is used in or the material used to process, but rather from the purpose of the process on a more general level. The created categorisation divided industrial side streams based on their origin into process residue materials, process residual energy, energy production residues and process residual structural components.

Originality/value: This study provides a tool for the preliminary technical and economic analysis of business cases based on industrial side stream utilisation and deepens the understanding of reusing industrial side streams as raw materials. The created categorisation can distinguish relevant properties affecting each side stream's reuse potential and guide the creation of business arising from their reuse.
\end{abstract}

Keywords: Circular economy, resource efficiency, industrial side streams, side stream utilisation, categorisation, reuse

\section{Introduction}

Industries worldwide are currently under pressure to reduce their environmental impact, which has provoked their interest in material efficiency and reusing materials traditionally disposed of (Korse et al., 2016; Schulte, 2013; Urbinati et al., 2017). Furthermore, the increasingly apparent need to find sustainable and economically viable alternatives to depleting resources has also created political incentives that support effective resource use and reuse (e.g., European Commission, 2011). However, the modern economy is still, for the most part, based on linearity (e.g., Lewandowski, 2016; Urbinati et al., 2017). As a result, business models and supply chains are optimised to create products as efficiently as possible, usually without circularity or sustainability (Schulte, 2013). This is very problematic from the environmental point of view, as climate change and resource scarcity are becoming more and more critical issues. Moreover, 
as the population grows and the standard of living rises outside the Western world, the pressure on natural resources will only increase in the future.

In a circular economy, waste is minimised, and value creation is maximised by utilising what has traditionally been considered waste as raw materials for other businesses in a similar way that nutrients circulate in nature (Bocken et al., 2013). Industries generate vast amounts of side streams in their operations, and there is a lot of underutilised potential in these materials that circular economy principles could harness. Industrial side streams result from industrial activities refining inputs or raw materials into outputs or products. As such, they are the unwanted but unavoidable result of the processes and materials used. If a side stream is deemed to be waste, it must be handled according to the legislation regarding wastes and in a way that does not harm the environment or human health (European Union, 2008).

It has been estimated that the European manufacturing industry could save up to 630 billion euros per year with more efficient resource use (INNOVA, 2012). Thus, there is a strong incentive to study and improve resource efficiency across the borders of industries. There is a lack of literature on the wider implications of industrial side stream utilisation, and existing references point out mainly the utilisation possibilities of certain side streams. This drives this study to look at the subject on a broader level and to study industrial side stream utilisation as a phenomenon. This includes studying industrial side streams and reusing them as raw material, the effects of circular economy principles on business ecosystems, value chains and business models, as well as current political attitudes towards a circular economy and circular materials.

Because the raw materials and processes used significantly affect the properties of consequent side streams, it is difficult to view all industrial side streams as one homogenous group. Different types of side streams present various challenges and opportunities in terms of their reuse. Thus, it would be beneficial for these industrial side streams to be categorised according to their properties affecting their reuse potential. There is a lack of literature on such categorisation, so a novel model is constructed in this study. The research questions set for this study are How can industrial side streams be categorised in the context of reuse potential evaluation? And, what are the properties of these categories? The categorisation will distinguish relevant properties affecting each side stream's reuse potential and guide the creation of business arising from their reuse. This study provides a tool for the preliminary technical and economic analysis of business cases based on industrial side stream utilisation. It deepens the understanding of reusing industrial side streams as raw materials.

\section{Materials and methods}

This study is based on a thorough literature review on the circular economy, industrial side stream utilisation, business ecosystems, business models, value chains, business case analysis, and productisation. The literature review consists mainly of industrial engineering and management, environmental engineering, and business literature, and it serves as a theoretical framework against which empirical studies are compared.

The empirical data for this multiple case study (Yin, 2003) was gathered from industries in Northern Ostrobothnia, Finland. Various data collection methods were utilised in each case, and multiple investigators collected the data. Data collection included company visits, interviews, workshops, seminars, and the collection of existing documentation from the cases. The data collected is mainly qualitative, but some quantitative data was also acquired.

The industrial side streams analysed for this study were mapped in workshops and during company visits. In addition, several experts and company representatives from different industrial sectors were interviewed to get a more profound understanding. The industrial side streams analysed include those from steelmaking, pulp and paper mills, construction, including 
waste wood and concrete, and ashes from power plants etc. All the case examples are listed in Table 1.

The empirical data was analysed using descriptive qualitative methods as introduced by Eisenhardt (1989). Cases were analysed and cross-referenced to draw conclusions from them. The empirical data was also compared with existing cases from the literature to find more reliable answers to the research questions set for this study. Figure 1 illustrates the research process.

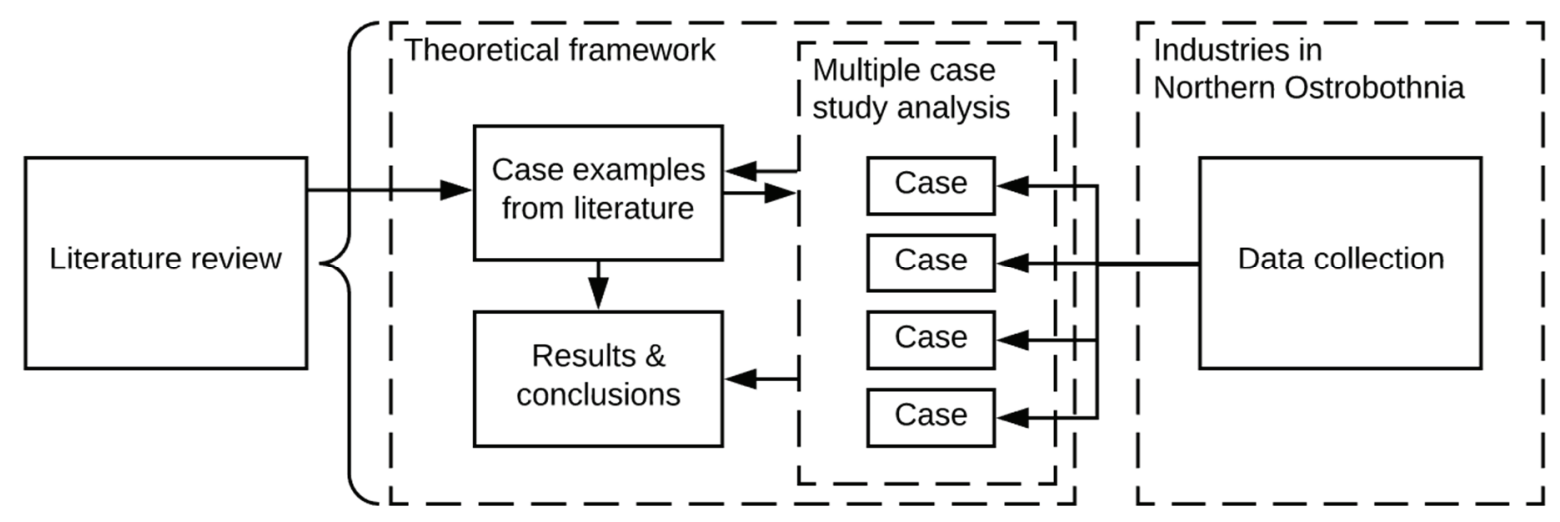

Figure 1: The research process

\section{Literature review}

\subsection{Circular economy}

The circular economy has attracted a lot of attention in recent years (e.g., Korse et al., 2016; Schulte, 2013; Urbinati et al., 2017) as the need to reduce emissions and waste generation and improve material efficiency have become more and more apparent. Instead of extracting the utility from resources and disposing of them after use, the circular economy aims to sustain the utility of resources within the economy (Korse et al., 2016). According to Urbinati et al. (2017), the starting point of all circular economy business models is to lengthen the usable lifespan of products compared to traditional linear business models. In the circular economy, linear business models are replaced with regenerative and restorative models to maximise material efficiency. As a result, waste is minimised and value creation maximised by recycling materials in interlinked production life cycles (Nußholz, 2017; Schulte, 2013). Schulte (2013) sums up the circular economy concept using five fundamental principles: minimise waste, identify and consider the whole ecosystem, maximise flexibility, use renewable energy, and maximise energy efficiency.

\subsection{Industrial side stream utilisation}

Industrial side streams are the result of industrial activities refining inputs or raw materials into outputs or products. These side streams are the unwanted but unavoidable result of the processes and the materials used. One challenge in industrial side stream utilisation, and waste utilisation in general, is that the definition of waste is very hard to pinpoint, and over-regulating waste with wide definitions endangers reusing potential resources from these materials (Tromans, 2001). According to Park and Chertow (2014), "[...], a material becomes waste not solely because of its physical and/or chemical characteristics, but principally because of the mismatch between its generation and consumption". If a side stream is deemed to be waste in the European Union, it must be handled according to the European Union's legislative framework for the handling of waste in the Community, which establishes major principles, for example, an 
obligation to handle waste in a way that does not have a negative impact on the environment or human health (European Union, 2008).

End-of-waste is a term that implies that waste has been transformed into a product or a secondary raw material and is no longer considered waste. The European Waste Framework Directive 2008/98/EC defines four criteria for an end-of-waste case:

- $\quad$ "The substance or object is commonly used for specific purposes;

- $\quad$ There is an existing market or demand for the substance or object;

- $\quad$ The use is lawful (substance or object fulfils the technical requirements for the specific purposes and meets the existing legislation and standards applicable to products);

- $\quad$ The use will not lead to overall adverse environmental or human health impacts."

One distinct feature of industrial side streams is price ambivalence, which means that their value can range from positive to negative depending on the circumstances they are produced in, for example (Baumgärtner, 2004). According to Baumgärtner (2004), three conditions define whether a secondary output of production is price ambivalent:

- The supply of material is not dependent on its price and demand.

- Options for its substitution are limited due to market conditions or technical requirements.

- $\quad$ The only alternative to reuse is costly disposal.

One challenge in circular economy and industrial side stream utilisation is contaminated interaction, which means an object's contamination due to its past use. Contaminated interaction can result in objects losing their appearance or material purity, for example (Baxter et al., 2017). According to Baxter et al. (2017), there are three types of contamination in circular economy material flows: technical contamination means a contaminant or a change in physical properties that makes material unusable, systemic contamination means a contaminant or a change in physical properties that has a negative effect on material flows, and interaction contamination means that the actual or imagined property alters how users perceive and engage with materials.

\subsection{Business ecosystems}

Moore (1993) introduced the concept of business ecosystems and stated that a company should not be viewed as a single entity of a single industry but instead as a member of a business ecosystem that can breach industry borders. Moore (1993) emphasises the importance of stakeholders and describes the concept of a business ecosystem as a loosely connected business community composed of different levels of organisations sharing a common goal and coevolving to deal with uncertain business environments. According to Rong et al. (2013), the concept of a business ecosystem equips companies with a more comprehensive view of crossindustry collaboration, rather than just directly linking partners in the supply chain. A company's value chain can be thought of as interconnected, with the value chains of its key partners in the business ecosystem. These interlinked value chains form a value network that is very similar to the concept of a business ecosystem. (Berndt, 2003; Porter, 2001; Tsvetkova \& Gustafsson, 2012)

Business ecosystems usually consist of core technology, product or service and an interconnected network of actors. Their motivation to participate in an ecosystem is that they can extract more value when co-creating with other actors in the ecosystem, which also makes them dependent on each other in their value creation. (Iansiti \& Levien, 2004; Peltoniemi, 2006) This interdependency of ecosystem actors, the complexity of the relationship between members 
and the simultaneous cooperation and competition are general risks associated with being part of any business ecosystem (Smith, 2013). The more interdependent ecosystem actors are, the more likely they are to run into problems. This is because ecosystem actors may not have any influence over the actors they are dependent on. As actors' relationships within the ecosystem have a strong influence over its success, the ecosystem's overall health can be studied by assessing them. (Adner \& Kapoor, 2010) Industrial symbioses are an example of very close cooperation and strong relationships between actors in a business ecosystem. According to Chertow [(2000), pp.313], industrial symbiosis "engages traditionally separate industries in a collective approach to competitive advantage involving physical exchange of materials, energy, water, and/or by-products. The keys to industrial symbiosis are collaboration and the synergistic possibilities offered by geographic proximity." The term by-product is used here, but, in our definition, an industrial side stream becomes a by-product only when produced into a repeatable and saleable product.

A healthy business ecosystem can offer its members stable and predictable relationships with other members of the ecosystem and reliable value creation (Iansiti \& Levien, 2004). According to Iansiti and Levien (2004), there are three ways the health of a business ecosystem can be evaluated: productivity, robustness and niche creation. Productivity means an ecosystem's ability to continuously self-renew (Iansiti \& Levien, 2004). Business ecosystems are similar to ecological ecosystems in that evolution is necessary for survival (Moore, 1993). Robustness refers to an ecosystem's ability to survive external disturbances and its predictability. Niche creation means an ecosystem's ability to support its diversity. A diverse ecosystem is better prepared to withstand external shocks and has better potential for innovation (Iansiti \& Levien, 2004). A critical aspect of a healthy, well-functioning business ecosystem is the alignment of different actors' strategies, as clashing incentives between members can damage the health of an ecosystem (Letaifa, 2014).

A circular economy changes traditional business ecosystems as it replaces the current takemake-dump production model with a new pattern: resources-products-waste-renewable resources (Urbinati et al., 2017). A modern and sustainable ecosystem needs new key partners, key resources, and key activities to create and deliver value effectively and according to the principles of the circular economy. Business ecosystems are inherently linked to value chains, which means that implementing circular strategies requires companies to rethink the value creation mechanism in their business ecosystem to ensure economic benefits. (Nußholz, 2017) For example, Moore (1993) has compared business networks to nature's ecosystems, showing that reforming business ecosystems to fit the principles of the circular economy could take a lot of inspiration from nature. Schulte (2013) points out that there is no concept of waste in nature, and everything is merely an input to another process in the ecosystem.

\subsection{Business models}

A variety of different definitions for the concept of business models can be found in the literature. Teece (2010) states that the term business model refers primarily to the conceptual level of how a business functions. Magretta (2002) defines a business model as a story that explains how the company works and describes the fundamental blocks around which its operations are built: customers, customer value, monetisation and value delivery. According to Osterwalder et al. (2005), a business model is essentially a tool to define the value creation logic of a company's business opportunity, a blueprint of its strategic positioning and goals, and a plan for designing its business structure. Ahokangas and Myllykoski (2014) argue that business models are built around two key blocks: business opportunity and competitive advantage. 
All business models must be based on a valuable problem (Roos 2014). If a business model is a solution without a problem, it is doomed to fail (Magretta 2002). This leads to the conclusion that the root of a successful business model is a valued solution paired with a valuable problem. According to Fielt (2013), these two parts are the fundamental thinking behind the concept of business models: creating value to customers and capturing part of this value. Achtenhagen et al. (2013) point out that business models are dynamic and need to change over time to achieve sustained value creation. Only through dynamic change is it possible to take advantage of new opportunities and to reduce the risk of stagnation that usually affects any successful business (Achtenhagen et al., 2013). Magretta (2002) notes that a successful new model can change the whole economics of an industry, giving its creator a strong competitive advantage.

According to Urbinati et al. (2017), the starting point of all circular economy business models is elongating a product's usable lifespan compared to a linear business model or using disposable products as a raw material source. Urbinati et al. (2017) recognised four levels of circularity in general business models. The first level is the traditional business models that are completely linear and do not apply circular economy principles in any way. Second, downstream circular business models have implemented pricing or marketing based on the use and reuse of their products. Third, upstream circular business models have implemented circular economy principles in their design process and supply chain. Finally, there are entirely circular business models where circular economy principles are implemented throughout the value creation and capturing process. (Urbinati et al., 2017) Roos (2014) notes that continuous value capture is essential for a circular business model. An efficient value chain is needed so that every step of the transformation process, from inputs to delivering an offering, adds value to the system.

\subsection{Value chains}

Porter (1985) introduced the concept of value chains, defining the required activities for a company to produce and deliver its offering to its customers (Porter 2001). According to Magretta (2002), business models are inherently linked to the concept of value chains, as they are simply variations of the generic value chain consisting of primary activities and secondary activities supporting them. The primary activities include inbound logistics, production processes, outbound logistics, marketing and sales and after-sales services. Secondary activities include the organisation infrastructure, technology development, human resource management and procurement. (Berndt, 2003; Porter, 2001)

The core idea of value chains is that every process in a company adds value and that every process should be optimised to create as much value as possible. According to Monden (1993), businesses that manufacture products have three types of operations: 1. Non-value adding (NVA), 2. Necessary but non-value-adding (NNVA), and 3. Value-adding (VA). The first type (NVA) is entirely unnecessary and should be removed completely. However, the second type (NNVA) is necessary for making products, but removing them would require considerable changes to production systems. The third type (VA) increases the value of the end product directly. (Monden, 1993) Berndt (2003) argues that the concept of value chains helps companies to identify their key resources and assets that give them a competitive advantage and enables them to focus on value-adding activities.

The circular value chain is built on the principles of circular economy, according to Roos (2014). It aims at maximum resource efficiency by minimising all inputs. Processing should be efficient, and losses in energy, material and water balances should be minimal. Side streams and waste should be captured, and their value potential utilised efficiently according to the European Commission's (2008) Waste Framework Directive's 5-step hierarchic approach to 
reduce waste generation: prevention, preparing for reuse, recycling, another recovery (such as energy recovery) and disposal. (Roos, 2014)

\subsection{Business case analysis}

Business case analysis is a method used to describe the business potential of different types of investments, to decide whether those investments should be made, and which options to choose from among them. The business case analysis defines the investment proposition. According to Berghout and Tan (2013), it can save resources by focusing attention on the critical parts of the project, thus helping to identify unviable projects before committing a lot of resources to them. (Berghout \& Tan, 2013; Korse et al., 2016) According to Kinnunen et al. (2011), the business case analysis consists of market assessment, technical assessment, financial analysis and finally, decision-making.

Market assessment defines the value of the proposed investment. It identifies the customer need, the benefits of the proposition, the opportunity window, the size of the target market and its growth rate. It also considers the current competitive situation in the market. The technical assessment explores the technical complexity of the proposition and the availability of required capabilities and skills to fulfil it. Based on those, it gives an estimation of the total work effort and resources needed. Of the three aspects of business case analysis, the technical assessment is the most prevalent in analysing costs, as, without sufficient technical understanding, it is impossible to make accurate estimations. The financial analysis utilises the information gathered during the market and technical assessment in calculating the sales and cost estimates for the proposition and, as an end result, presents a numeric value on the economic feasibility of the proposition. (Kinnunen et al., 2011) Kinnunen et al. (2011) also note that it is usually essential to assess the strategic fit of the evaluated proposition. According to Cooper (2008), the strategic fit assessment means assessing whether the proposition is aligned with the company's strategy, its importance, and its impact on business.

Most business case analysis frameworks do not include sustainability in the evaluation process, even though resource efficiency and circular economy are becoming more important to consider when making business decisions. However, it can be included in technical assessment, for example, in the sense of material technology advancement or market assessment, for example, changing customer preferences (Kinnunen et al., 2011). Korse et al. (2016) developed an enhanced business case framework for sustainability by applying the circular economy principles. They identified three core elements for assessing the environmental sustainability of the proposition: resource usage, ecological footprint, and environmental impact. (Korse et al., 2016)

\subsection{Productisation}

Productisation means the set of activities required to turn technologies and services into saleable products that are repeatable, comprehensible, and standardised (Härkönen et al., 2015). According to Härkönen et al. [(2015), pp.70], the productisation of physical products, with both tangible and intangible features, "[...] involves engineering-related aspects and supports the development of products and their introduction to the market. Productization has a specific role along with these functions."

Circular materials can be challenging from a productisation point of view if there is a possibility to utilise virgin materials or other traditional alternatives in the same context. Korpijärvi et al. (2009) list such factors to be: 1. legislative constrictions considering the use of certain materials; 2. the negative connotations about the term "waste", reminding us of a hazardous material or inferior quality; 3 . negative attitudes towards refining waste-derived materials; 4. lack of 
knowledge of the material, its properties and availability; and 5. procurement practices. Korpijärvi et al. (2009) approached this subject from an earthmoving materials point of view, but the challenges, especially those related to attitudes towards waste, seem to be a recurring theme in the literature about waste utilisation (e.g., Baumgärtner, 2004; Baxter et al., 2017; Park \& Chertow, 2014).

\section{Creating the categorisation}

Based on the empirical data gathered for this study, it can be concluded that certain types of processes yield certain types of industrial side streams. In the scope of this study, the similarities between these secondary outputs of processes seem not to originate from either the industry the process is used in or the material used to process, but from the nature of the process on a more general level. The initial classification was created based on the empirical business cases studied, and it was adjusted according to feedback given by experts during workshop sessions. The four types of industrial side streams based on the types of processes they are generated in are presented below:

- Type 1: Process residue material

- Type 2: Process residual energy

- Type 3: Energy production residue

- Type 4: Process residual structural components

This categorisation divides industrial side streams based on their origin into four types, each with typical challenges and opportunities associated with them. All side stream types have their own distinct properties affecting their reuse potential. As such, this categorisation should be able to guide the creation of business arising from the reuse of industrial side streams. For example, even though process residual energy and energy production residue are technically both process residues that could be categorised under type 1 side streams, their different nature justifies three different categories. Other types of side streams are also acknowledged to exist, but they were found to be irrelevant in the context of this study. For example, unused components or raw materials that are no longer suitable for further use can be considered surplus-type side streams.

\subsection{Type 1: Process residue materials}

Type 1 side streams are process residue materials generated in processes that separate materials from the raw materials to form the primary product. The processes resulting in type 1 side streams do not extract energy from raw materials, and energy is not introduced in the process in abundant quantities. Examples of type 1 side streams are fibre sludge from paper mill water purification, metal swarf from machining industries, or wood chips and sawdust from sawmill industries. Variability between type 1 side streams is the largest from the side stream types identified in this study, and the degree of contamination also varies a lot. In mechanical processes, the consequent side stream will closely resemble the raw materials' structure with usually a very low level of contamination, as opposed to chemical processes that use chemicals to process raw materials and where side streams are likely to contain some contaminants from the chemicals used. Often with type 1 side streams, there is a possibility to feed side streams back into the production processes; for example, metal swarf can be refined back into metals. One advantage of type 1 side streams is that there is usually a very steady supply and predictable quality. Figure 2 illustrates how type 1 side streams are generated. 


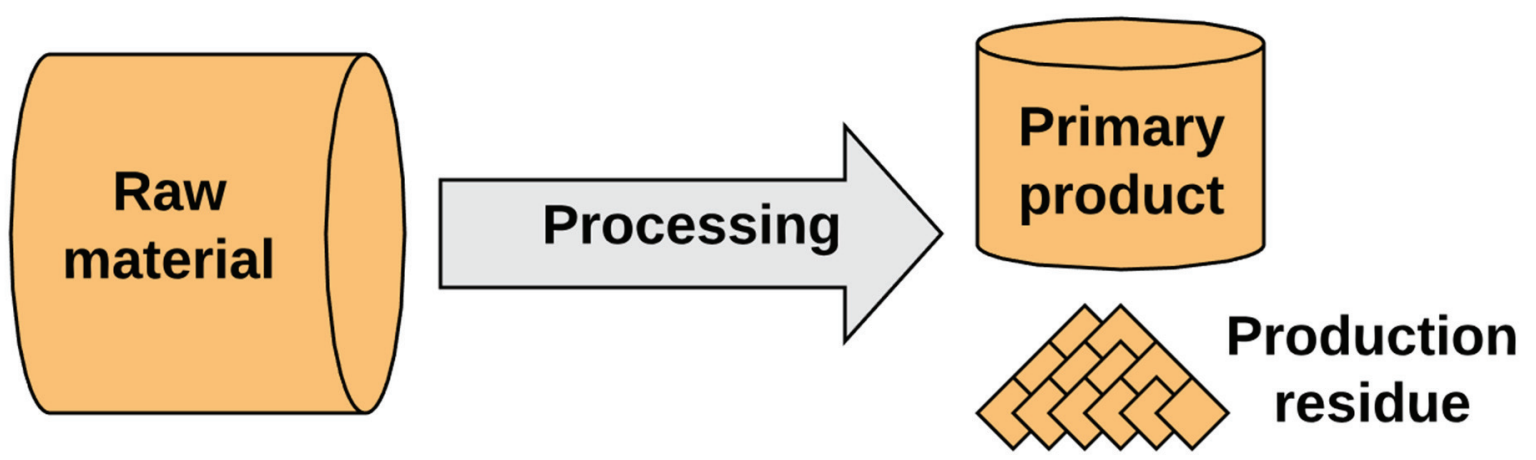

Figure 2: How type 1 side streams are generated

\subsection{Type 2: Process residual energy}

A type 2 side stream is a process of residual energy usually generated in high-energy processes. The energy introduced in the process is challenging to transfer into the target material efficiently. This means a lot of energy is wasted in heating the surroundings, vessels, and materials other than the material that ends up in the primary product. Metal casting and steelmaking are prime examples of processes resulting in type 2 side streams. In steelmaking, large amounts of materials are heated to a very high temperature along with impurities and additives, forming slag that exits the process at a very high temperature. Another example of a type 2 side stream is the waste heat generated by data centres which use large amounts of electricity, the majority of which is transformed into heat. Figure 3 illustrates how type 2 side streams are generated.
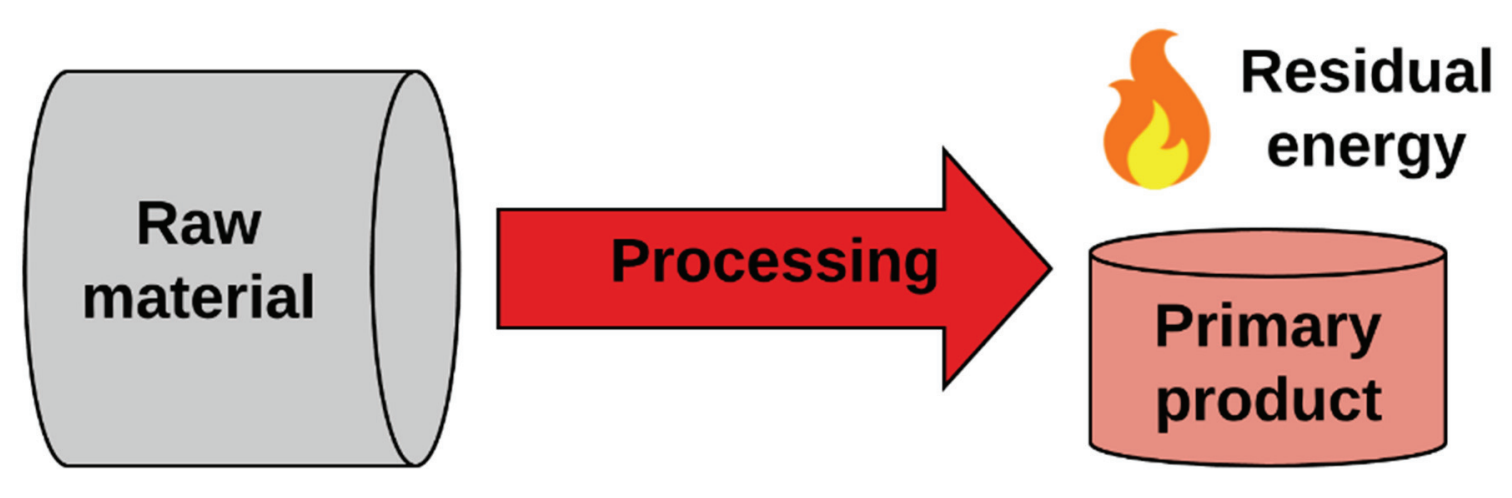

Figure 3: How type 2 side streams are generated

\subsection{Type 3: Energy production residue}

A type 3 side stream is energy production residue generated in processes that extract energy from raw materials. Energy production residue is usually formed from non-combustible compounds when the energy content of raw materials is released in the form of heat energy. Combustion processes are therefore typical processes yielding type 3 side streams which are usually different types of ashes. The consistency of type 3 side streams is determined by the raw material used, and some ashes may contain heavy metals or other toxic compounds, limiting their reusability. Another problem with ashes is that they are very prone to dusting, which makes transporting them challenging. The reasoning behind creating a separate category for these materials is their universally large production volumes and the special refining possibilities found in these side streams. Figure 4 illustrates how type 3 side streams are generated. 

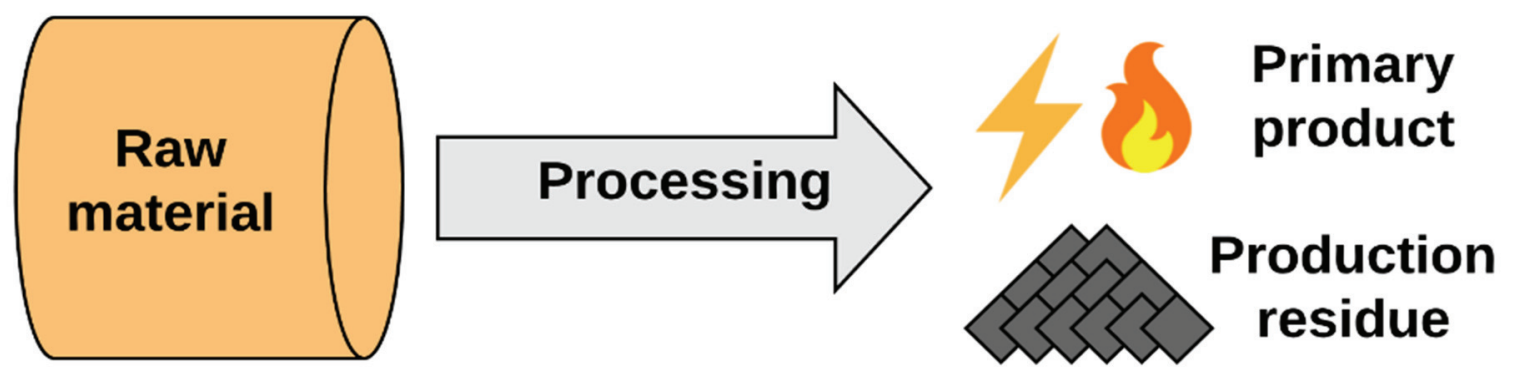

Figure 4: How type 3 side streams are generated

\subsection{Type 4: Process residual structural components}

Type 4 side streams are process residual structural components that include disassembled structural supports and parts used in processes. Type 4 side streams are usually relatively intact but suffer from varying degrees of contamination from the processes they were used in. Examples of type 4 side streams would be concrete moulding and sand-casting residues from foundries or timber used as temporary support in the construction industry. Processes that disassemble existing structures like the demolition of buildings or other structures result in type 4 side streams in the form of waste concrete, wood, and other materials. Usually, these materials are disposed of and landfilled, even though the disposal costs related to them are relatively high. The main challenges of type 4 side streams in the context of this study are fluctuating supply, scattered production, unpredictable quality, and contaminants being difficult to remove. Recycling materials such as paper, plastic or metal also falls under this category. Figure 5 illustrates how type 4 side streams are generated.
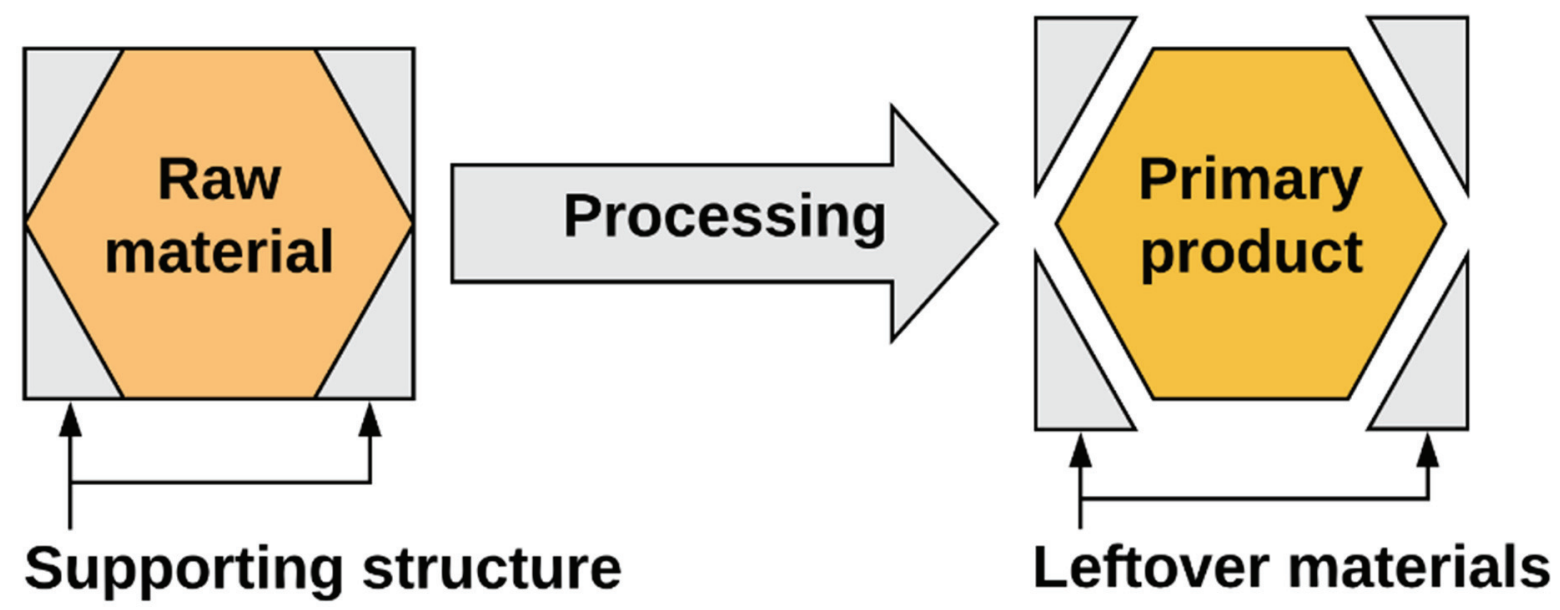

Figure 5: How type 4 side streams are generated

\section{Results}

Based on the literature review and the empirical business cases studied, the necessary considerations and typical characteristics affecting the reuse potential of these four aforementioned industrial side stream types are presented in Table 1. 
Table 1: Typical properties of side stream types and considerations in their reuse

\begin{tabular}{|c|c|c|c|c|}
\hline Side stream type & $\begin{array}{l}\text { Type 1: Process residue } \\
\text { material }\end{array}$ & $\begin{array}{l}\text { Type 2: Process } \\
\text { residual energy }\end{array}$ & $\begin{array}{l}\text { Type 3: Energy } \\
\text { production residue }\end{array}$ & $\begin{array}{l}\text { Type 4: Process residual } \\
\text { structural components }\end{array}$ \\
\hline Alternative costs & $\begin{array}{l}\text { Alternative costs in } \\
\text { disposal, price ambivalent }\end{array}$ & $\begin{array}{l}\text { No alternative costs, not } \\
\text { price ambivalent }\end{array}$ & $\begin{array}{l}\text { Alternative costs in } \\
\text { disposal, price } \\
\text { ambivalent }\end{array}$ & $\begin{array}{l}\text { Alterative costs in } \\
\text { disposal, price ambivalent }\end{array}$ \\
\hline Contamination & $\begin{array}{l}\text { Varying amounts } \\
\text { depending on the processes }\end{array}$ & $\begin{array}{l}\text { Minimal or non-existent } \\
\text { amounts }\end{array}$ & $\begin{array}{l}\text { Usually, varying } \\
\text { amounts of heavy metals } \\
\text { or other toxic compound } \\
\text { residues }\end{array}$ & $\begin{array}{l}\text { It varies but usually exists } \\
\text { to some extent }\end{array}$ \\
\hline Supply & $\begin{array}{l}\text { Usually, a steady supply } \\
\text { with reliable quality }\end{array}$ & $\begin{array}{l}\text { Often a very steady } \\
\text { supply }\end{array}$ & $\begin{array}{l}\text { A very steady supply } \\
\text { with reliable quality }\end{array}$ & $\begin{array}{l}\text { Often a fluctuating supply } \\
\text { and scattered production } \\
\text { with varying quality }\end{array}$ \\
\hline $\begin{array}{l}\text { Ecosystem } \\
\text { requirements }\end{array}$ & $\begin{array}{l}\text { The variability between } \\
\text { type } 1 \text { side streams is the } \\
\text { largest, and thus some } \\
\text { cases require stronger } \\
\text { relationships between } \\
\text { actors than others. }\end{array}$ & $\begin{array}{l}\text { Utilisation requires } \\
\text { functioning industrial } \\
\text { symbiosis between the } \\
\text { source of residual energy } \\
\text { and its utiliser. }\end{array}$ & $\begin{array}{l}\text { Requires a functioning } \\
\text { ecosystem around } \\
\text { utilisation }\end{array}$ & $\begin{array}{l}\text { Requires a stable } \\
\text { utilisation ecosystem with } \\
\text { a multitude of different } \\
\text { actors, such as side stream } \\
\text { producers, refiners, } \\
\text { utilisers and transportation }\end{array}$ \\
\hline $\begin{array}{l}\text { Considerations } \\
\text { in reusing }\end{array}$ & $\begin{array}{l}\text { Usually, some possibilities } \\
\text { of refining or feeding back } \\
\text { into the production } \\
\text { process. } \\
\text { In-house vs external } \\
\text { utilisation requires a } \\
\text { different strategical focus } \\
\text { Steady supply and reliable } \\
\text { quality allow the creation } \\
\text { of standardised products }\end{array}$ & $\begin{array}{l}\text { Local demand is vital } \\
\text { since transporting or } \\
\text { storing process residual } \\
\text { energy is not technically } \\
\text { feasible } \\
\text { The possibilities in } \\
\text { residual energy } \\
\text { utilisation should be } \\
\text { taken into account very } \\
\text { early on in the planning } \\
\text { phase of processes and } \\
\text { facilities that will } \\
\text { generate residual energy }\end{array}$ & $\begin{array}{l}\text { The level of } \\
\text { contamination is usually } \\
\text { high, which affects the } \\
\text { reuse potential and can } \\
\text { cause problems with the } \\
\text { legislation, for example } \\
\text { Some unique } \\
\text { possibilities in refining, } \\
\text { for instance, into } \\
\text { granules or geopolymers }\end{array}$ & $\begin{array}{l}\text { Fluctuating supply requires } \\
\text { agile production methods } \\
\text { Some legislative } \\
\text { restrictions exist, for } \\
\text { example for the use of } \\
\text { construction waste } \\
\text { materials } \\
\text { Varying quality makes } \\
\text { utilisation and creating } \\
\text { standardised products } \\
\text { challenging }\end{array}$ \\
\hline $\begin{array}{l}\text { Analysed case } \\
\text { examples }\end{array}$ & $\begin{array}{l}\text { Steel mill side streams, } \\
\text { pulp and paper mill side } \\
\text { streams, limestone } \\
\text { processing side streams, } \\
\text { fish farming side streams }\end{array}$ & $\begin{array}{l}\text { Waste heat from metal } \\
\text { casting and steelmaking } \\
\text { slag, waste heat from } \\
\text { data centres }\end{array}$ & Fluidised bed CHP ash & $\begin{array}{l}\text { Waste concrete, wood, } \\
\text { mineral wool and glass } \\
\text { from the construction } \\
\text { industry, waste fibre optic } \\
\text { cable }\end{array}$ \\
\hline
\end{tabular}

\section{Conclusions}

Based on the literature review conducted and the empirical business cases studied, this study created a novel categorisation of industrial side streams in the context of potential reuse evaluation. The created categorisation differentiates between side streams based on the industrial processes they are produced in. Furthermore, the side streams were categorised according to their method of generation, as the similarities between side streams in the scope of this study were found not to originate from either the industry the process is used in or the material used to process, but rather from the purpose of the process on a more general level. Thus, the results of this study deepen the understanding of reusing industrial side streams as raw materials in business cases, and the created categorisation serves as a tool for preliminary economic and technical analysis of such cases in the future. Furthermore, the created categorisation can distinguish between relevant properties affecting each side stream type's reuse potential and thus guide the creation of business arising from their reuse.

The limitations of this study are primarily a matter of scope, as the study was done in the context of Finland and Northern Ostrobothnia's industrial field. If the study were to be repeated in a 
different context, it is plausible that the results and the side stream types found would differ. Furthermore, the authors recognise that other types of side streams exist. Still, they were not relevant in the scope of this study as the generated categorisation was created to fit the empirically studied case examples. One can also argue that the industrial side stream cases chosen for analysis do not form a large enough sample size to create such a categorisation and draw reliable conclusions about each side stream type's reuse potential.

As for further research implications, more in-depth research should be conducted into the roles and unique characteristics different approaches to creating a business from industrial side streams have. Particularly from the perspective of business ecosystems and business models, it would be beneficial to identify the special features these industrial side stream utilisation-based business cases have compared to traditional models. In addition, research into the productisation of these industrial side streams into repeatable and saleable by-products ought to be conducted. Further research could also be done on the implications of industrial side stream utilisation on new product development processes and production planning. Finally, more research on an industry-wide level, for example, in the steel manufacturing industry, should be conducted to find new utilisation possibilities for currently underutilised side streams.

\section{References}

Achtenhagen, L., Melin, L., \& Naldi, L. (2013). Dynamics of Business Models - Strategising Critical Capabilities and Activities for Sustained Value Creation. Long Range Planning, 46(6), 427-442. https://doi.org/10.1016/j.lrp.2013.04.002

Adner, R., \& Kapoor, R. (2010). Value creation in innovation ecosystems: How the structure of technological interdependence affects firm performance in new technology generation. Strategic Management Journal, 31, 306-333. https://doi.org/10.1002/smj.821

Ahokangas, P., \& Myllykoski, J. (2014). The Practice of Creating and Transforming a Business Model. Journal of Business Models, 2(1), 6-18. https://doi.org/10.5278/ojs.jbm.v2i1.719

Baumgärtner, S. (2004). Price ambivalence of secondary resources: joint production, limits to substitution and costly disposal. Resources, Conservation and Recycling, 43(1), 95-117. https://doi.org/10.1016/j.resconrec.2004.04.013

Baxter, W., Aurisicchio, M., \& Childs, P. (2017). Contaminated Interaction: Another Barrier to Circular Material Flows. Journal of Industrial Ecology, 21(3), 507-516. https://doi.org/10.1111/jiec.12612

Berghout, E., \& Tan, C-W. (2013). Understanding the impact of business cases on IT investment decisions: An analysis of municipal e-government projects. Information \& Management, 50(7), 489-506. https://doi.org/10.1016/j.im.2013.07.010

Berndt, A.D. (2003). Leadership in the value chain, Acta Commercii, 3(1). https://doi.org/10.4102/ac.v3i1.35

Bocken, N.M.P., Short, S.W., Rana, P., \& Evans, S. (2013). A literature and practise review to develop sustainable business model archetypes. Journal of Cleaner Production, 65, 42-56. https://doi.org/10.1016/j.jclepro.2013.11.039

Chertow, M.R. (2000). Industrial symbiosis: Literature and Taxonomy. Annual Review of Energy and the Environment, 25, 313-337. https://doi.org/10.1146/annurev.energy.25.1.313

Cooper, R.G. (2008). Perspective: The Stage-Gate Idea-to-Launch Process-Update, What's New, and NexGen Systems. Journal of Product Innovation Management, 25(3), 213-232. https://doi.org/10.1111/j.15405885.2008.00296.x

Eisenhardt, K.M. (1989). Building Theories from Case Study Research. The Academy of Management Review, 14(4), 532-550. https://doi.org/10.2307/258557

European Commission (2011). Communication from the Commission to the European Parliament, the Council, the European Economic and Social Committee and the Committee of the Regions - Roadmap to a Resource Efficient Europe. Retrieved from https:/eur-lex.europa.eu/legalcontent/EN/TXT/?uri=CELEX:52011DC0571

European Union (2008). Directive 2008/98/EC of the European Parliament and of the Council of 19 November 2008 on waste and repealing certain Directives. Official Journal of the European Union, 312, 3-30. http://data.europa.eu/eli/dir/2008/98/oj

Fielt, E. (2013). Conceptualising Business Models: Definitions, Frameworks and Classifications. Journal of Business Models, 1(1), 85-105. https://doi.org/10.5278/ojs.jbm.v1i1.706

Härkönen, J., Haapasalo, H., \& Hänninen, K. (2015). Productisation: A review and research agenda. International Journal of Production Economics, 164, 65-82. https://doi.org/10.1016/j.ijpe.2015.02.024 
Iansiti, M., \& Levien, R. (2004). Strategy as Ecology. Harvard Business Review, 82(3), 68-78.

INNOVA (2012). Guide to resource efficiency in manufacturing: Experiences from improving resource efficiency in manufacturing companies. Retrieved from https:/www.greenovateEurope.EU/sites/default/files/publications/REMake_Greenovate\%21Europe\%20$\% 20$ Guide $\% 20$ to $\% 20$ resource $\% 20$ efficient $\% 20$ manufacturing\%20\%282012\%29.pdf

Kinnunen, T., Pekuri, A., Haapasalo, H., \& Kuvaja, P. (2011). Business case analysis in new product development. Global Journal of Management and Business Research, 11(2).

Korpijärvi, K., Mroueh, U., Merta, E., Laine-Ylijoki, J., Kivikoski, H., Järvelä, E., Wahlström, M., \& Mäkelä, E. (2009). Energiantuotannon tuhkien jalostaminen maarakennuskäyttöön. Research note (2499) VTT Technical Research Centre of Finland.

Korse, M., Ruitenburg, R.J., Toxopeus, M.E., \& Braaksma, A.J.J. (2016). Embedding the Circular Economy in Investment Decision-making for Capital Assets - A Business Case Framework. Procedia CIRP, 48, 425430. https://doi.org/10.1016/j.procir.2016.04.087

Letaifa, S. (2014). The uneasy transition from supply chains to ecosystems: The value creation/value-capture dilemma. Management Decision, 52(2), 278-295. https://doi.org/10.1108/MD-06-2013-0329

Lewandowski, M. (2016). Designing the Business Models for Circular Economy - Towards the Conceptual Framework. Sustainability, 8(1), 43. https://doi.org/10.3390/su8010043

Magretta, J. (2002). Why business models matter. Harvard Business Review, 80(5), 86-92.

Monden, Y. (1993). Toyota Production System - An Integrated Approach to Just-in-Time (2nd ed.). Industrial Engineering and Management Press, Norcross, GA.

Moore, J.F. (1993). Predators and prey: a new ecology of competition. Harvard Business Review, 71(3), 75-86.

Nußholz, J.L.K. (2017). Circular Business Models: Defining a Concept and Framing an Emerging Research Field. Sustainability, 9(10), 1810. https://doi.org/10.3390/su9101810

Osterwalder, A., Pigneur, Y., \& Tucci, C.L. (2005). Clarifying Business Models: Origins, Present and Future of the Concept. Communications of the Association for Information Systems, 16, 1-25. https://doi.org/10.17705/1CAIS.01601

Park, J.Y. \& Chertow, M.R. (2014). Establishing and testing the "reuse potential" indicator for managing wastes as resources. Journal of Environmental Management, 137, 45-53. https://doi.org/10.1016/j.jenvman.2013.11.053

Peltoniemi, M. (2006). Preliminary theoretical framework for the study of business ecosystems. Emergence: $\begin{array}{llll}\text { Complexity } \quad \text { Ond } & 8(1), & 10-19 .\end{array}$ https://doi.org/10.emerg/10.17357.8bb81e60d0fa815f83002ae1f418068c

Porter, M. (1985). Competitive advantage: Creating and sustaining superior performance. Free Press, New York.

Porter, M. (2001). Strategy and the Internet. Harvard Business Review, 79(5), 62-78.

Rong, K., Shi, Y., \& Yu, J. (2013). Nurturing business ecosystems to deal with industry uncertainties. Industrial Management \& Data Systems, 113(3), 385-402. https://doi.org/10.1108/02635571311312677

Roos, G. (2014). Business Model Innovation to Create and Capture Resource Value in Future Circular Material Chains. Resources, 3(1), 248-274. https://doi.org/10.3390/resources3010248

Schulte, U.G. (2013). New Business Models for a Radical Change in Resource Efficiency. Environmental Innovation and Societal Transitions, 9, 43-47. https://doi.org/10.1016/j.eist.2013.09.006

Smith, D. (2013). Navigating Risk When Entering and Participating in a Business Ecosystem. Technology Innovation Management Review, 3(5), 25-33. http://doi.org/10.22215/timreview/685

Teece, D.J. (2010). Business models, business strategy and innovation. Long Range Planning, 43(2-3), $172-194$. https://doi.org/10.1016/j.lrp.2009.07.003

Tromans, S. (2001). EC waste law: a complete mess? Journal of Environmental Law, 13(2), $133-156$. https://doi.org/10.1093/jel/13.2.133

Tsvetkova, A., \& Gustafsson, M. (2012). Business models for industrial ecosystems: a modular approach. Journal of Cleaner Production, 29-30, 246-254. https://doi.org/10.1016/j.jclepro.2012.01.017

Urbinati, A., Chiaroni, D., \& Chiesa, V. (2017). Towards a new taxonomy of circular economy business models. Journal of Cleaner Production, 168, 487-498. https://doi.org/10.1016/j.jclepro.2017.09.047

Yin, R.K. (2003). Case Study Research: Design and Methods (3rd ed.). SAGE Publications, Beverly Hills, CA. 